\title{
Characterization of Southern Illinois Water Treatment Residues for Sustainable Applications
}

\author{
Louis Akainya Ackah ${ }^{1, *(\mathbb{D})}$, Rajesh Guru ${ }^{1}$, Meisam Peiravi ${ }^{2}$ (D), Manoj Mohanty ${ }^{3}$, \\ Xingmao $\mathrm{Ma}^{4}{ }^{(\mathbb{D})}$, Sanjeev Kumar ${ }^{2}$ and Jia Liu ${ }^{2}$ \\ 1 Department of Mining \& Mineral Resources Engineering, Southern Illinois University, 1230 Lincoln Dr., \\ Carbondale, IL 62901, USA; rajguru1927@gmail.com \\ 2 Department of Civil \& Environmental Engineering, Southern Illinois University, 1230 Lincoln Dr., \\ Carbondale, IL 62901, USA; Meisam.Peiravi@yahoo.com (M.P.); kumars@ce.siu.edu (S.K.); \\ jia.liu@siu.edu (J.L.) \\ 3 Department of Mining \& Metallurgical Engineering, University of Nevada, Reno, 1664 N. Virginia St., Reno, \\ NV 89557, USA; manojmohantyunr@gmail.com \\ 4 Department of Civil Engineering, Texas A\&M University, 115-F DLEB College Station, TX 77843, USA; \\ xma@civil.tamu.edu \\ * Correspondence: akainya209@yahoo.com; Tel.: +1-614-477-9263
}

Received: 16 February 2018; Accepted: 19 April 2018; Published: 28 April 2018

\begin{abstract}
Although they are abundantly available, the specific applicability of water treatment residues (WTRs) is dictated largely by the favorability of physicochemical characteristic properties and mineralogical composition. We have suggested that WTRs have a high potential for remediation application. In addition, the relevant properties that define the beneficial reuse of WTRs may be widely variable due to the influence of the dose, type of coagulant/softening agent, and quality of source water. This study investigated the physical, chemical, agronomic, and mineralogical characteristics of three different types of WTRs that were collected from treatment plants in the Midwestern U.S, in order to compare and assess their suitability for remediating impacted ecosystems, such as abandoned mine lands (AML). An analysis of the results showed that the differences in the properties of the WTR samples were significant. The total metal concentrations by inductively coupled plasma mass spectrometry (ICP-MS) revealed the abundance of $\mathrm{Fe}, \mathrm{Al}, \mathrm{Mn}, \mathrm{Cu}$, and other co-occurring metals. The leachability of metal(loid)s, regulated under the Resource Conservation and Recovery Act (RCRA 8 metals), were below their respective US Environmental Protection Agency (EPA) allowable limits of 5.0, 100, 1.0, 5.0, 5.0, 0.2, 1.0, and $5.0 \mathrm{mg} / \mathrm{kg}$, indicating that the WTRs were non-hazardous to the environment. Comparatively, the Al-WTR showed a significant release of arsenic (As), possibly from livestock waste and pesticide application from farms in the catchment area of the raw water source. The WTRs were alkaline (potential of hydrogen $[\mathrm{pH}] 7.00-9.10$ ), which suggested a high acidity-neutralizing potential. The Ca:Mg ratio was between 1:7 and 1:1.5 (meq basis), which contributed to a cation exchange capacity (CEC) range of 4.6-16.2 meg/100g. The WTRs also showed adequate capability to supply relevant plant nutrients, such as $\mathrm{Zn}, \mathrm{Ca}, \mathrm{Mg}, \mathrm{S}, \mathrm{Cu}$, and Fe, although readily available concentrations of $\mathrm{NO}_{3}-\mathrm{N}, \mathrm{P}$, and $\mathrm{K}$ were generally low. Thus, the alkalinity, significant CEC, low metal concentration and the presence of $\mathrm{X}$-ray diffraction amorphous phases and calcites suggested that WTRs could be safely applied as low-cost sustainable alternatives for soil improvement and remediating contaminants such as metal(loid)s in AML.
\end{abstract}

Keywords: water treatment residue; coagulants; alum; ferric salt; lime; drinking water; sustainable reuse 


\section{Introduction}

The treatment processes that are utilized in the production of potable water include coagulation-filtration, granular activated carbon, precipitative softening, ion exchange, and membrane separation. Conventional coagulation-filtration drinking water treatment processes use inorganic chemicals (coagulants), such as alum $\left(\mathrm{KAl}\left[\mathrm{SO}_{4}\right]_{2} \cdot 12 \mathrm{H}_{2} \mathrm{O}\right)$ or ferric salts $\left(\mathrm{FeCl}_{3}\right.$, or $\left.\mathrm{Fe}_{2}\left[\mathrm{SO}_{4}\right]_{3}\right)$, to remove the suspended solid matter and natural organic matter in water by charge neutralization, sweep flocculation, and adsorption onto amorphous metal hydroxide precipitates [1]. Furthermore, precipitative softening plants primarily reduce hardness by raising the potential of hydrogen $(\mathrm{pH})$ in order to enhance the precipitation of calcium carbonate $\left(\mathrm{CaCO}_{3}\right)$ and magnesium hydroxide $\mathrm{Mg}(\mathrm{OH})_{2}$, using lime or soda ash. These treatment processes result in the production of byproducts known as water treatment residuals (WTRs) [2].

Mechanically dewatered residues are mostly processed for useful applications or they are disposed of by landfilling. In addition to landfilling as the major disposal method, residues may be discharged into rivers and oceans, injected in deep-wells, or diverted to on-site waste impoundments. Major setbacks to landfill disposal include tightened environmental regulations, declined public acceptance of landfill solutions, increased disposal costs, and decreased landfill capacity. The direct discharge into rivers and oceans is highly discouraged because of the potential impact on the aquatic environment. Deep-well injection, on the other hand, is comparatively cost prohibitive and can also impact underground sources of drinking water. The current high water quality requirements and high pollutant levels in source waters are responsible for the high dose application of coagulants/softeners. Subsequently, over 2 million metric tons of treatment residuals are produced daily from drinking water treatment plants in the U.S. [3]. Local availability of WTRs is an advantage to the sustainable application [4].

The major components of WTRs are soil separates, organic materials, hydrous metal hydroxides (the quantities of which depend on the type and dose of coagulant and/or liming agent that is used), and source water quality. Hence, WTRs exhibit major variabilities in physical, chemical, biological, and mineralogical composition [5-11]. Knowledge of the WTR material properties is, therefore, essential towards decision making for reuse. Over the last years, relentless efforts have been made toward the beneficial application of regenerated WTRs in order to help reduce the disposal volume. The current beneficial uses of WTR typically include land application for acidity correction, for agricultural or horticultural benefits, and scantily for other engineering applications [12-15]. Current studies have focused on WTRs for the removal of organic and inorganic contaminants from soil and aqueous systems. They are applied in aqueous solutions as sorbents of perchlorate, phosphate, dichromate, dyes, mercury, hydrogen sulfides, and ions of heavy metal and metalloids [5,16-26]. The effect of WTR application on the attenuation and mobility of phosphorus heavy metals and the metalloid arsenic in agricultural soils has also been studied extensively $[3,6,7,27-30]$. However, the application of WTRs for remediating mining impacted ecosystems have not received much attention. The current technologies that are used for soil and water remediation-such as vitrification, soil washing, total encapsulation, grouting, air stripping, precipitation, thermal desorption, reverse osmosis, and ion exchange-are costly, labor intensive, and require large amounts of energy resources.

Hence, the sustainable recycle and reuse of WTRs as a cost-effective and efficient alternative material for remediation of soil and water at identified abandoned mines sites. It would also provide a safe and beneficial disposal route for the otherwise solid waste, as regulated under the framework of the Resource Conservation and Recovery Act (RCRA) public law. This study has suggested that WTRs have a high potential for remediation application due to particular inherent properties and that, although WTRs may share common properties, a composition analysis of samples that were collected from different treatment facilities, would reveal significantly different levels of the relevant parameters that define beneficial reuse. WTRs samples were, therefore, collected from three drinking water treatment plants in the Southern Illinois region, in order to explore their potential for remediation application. Currently, to the best of our knowledge, no such assessments have been conducted on 
WTRs in the region, or on samples from the considered facilities. The study represented a useful addition to the literature by providing important information on regenerative alternatives to primary resources that are used in soil and water remediation projects.

\section{Materials and Methods}

\subsection{WTR Sample Collection and Preparation}

WTR samples were collected across the length of the dewatering ponds from three community drinking water treatment facilities in Southern Illinois in the United States, including the City of Carbondale Water Treatment Plant in Jackson County, IL; Rend Lake Conservancy District Water Treatment Plant in Franklin County, IL; and Saline Valley Conservancy District Water Treatment Plant in Saline County, IL. The City of Carbondale Water Treatment Plant utilized an alum coagulant to remove part of the total suspended solids and biochemical oxygen demand from the raw water. The Rend Lake Conservancy District Water Treatment Plant utilized a $\mathrm{FeCl}_{3}$ coagulant with $\mathrm{CaO}$ for precipitation and softening purposes. The Saline Valley Conservancy District Water Treatment Plant treated groundwater and produced a softening residue with high concentrations of $\mathrm{CaO}$. Figure 1 shows the county map of the State of Illinois with sample sources identified by their counties.

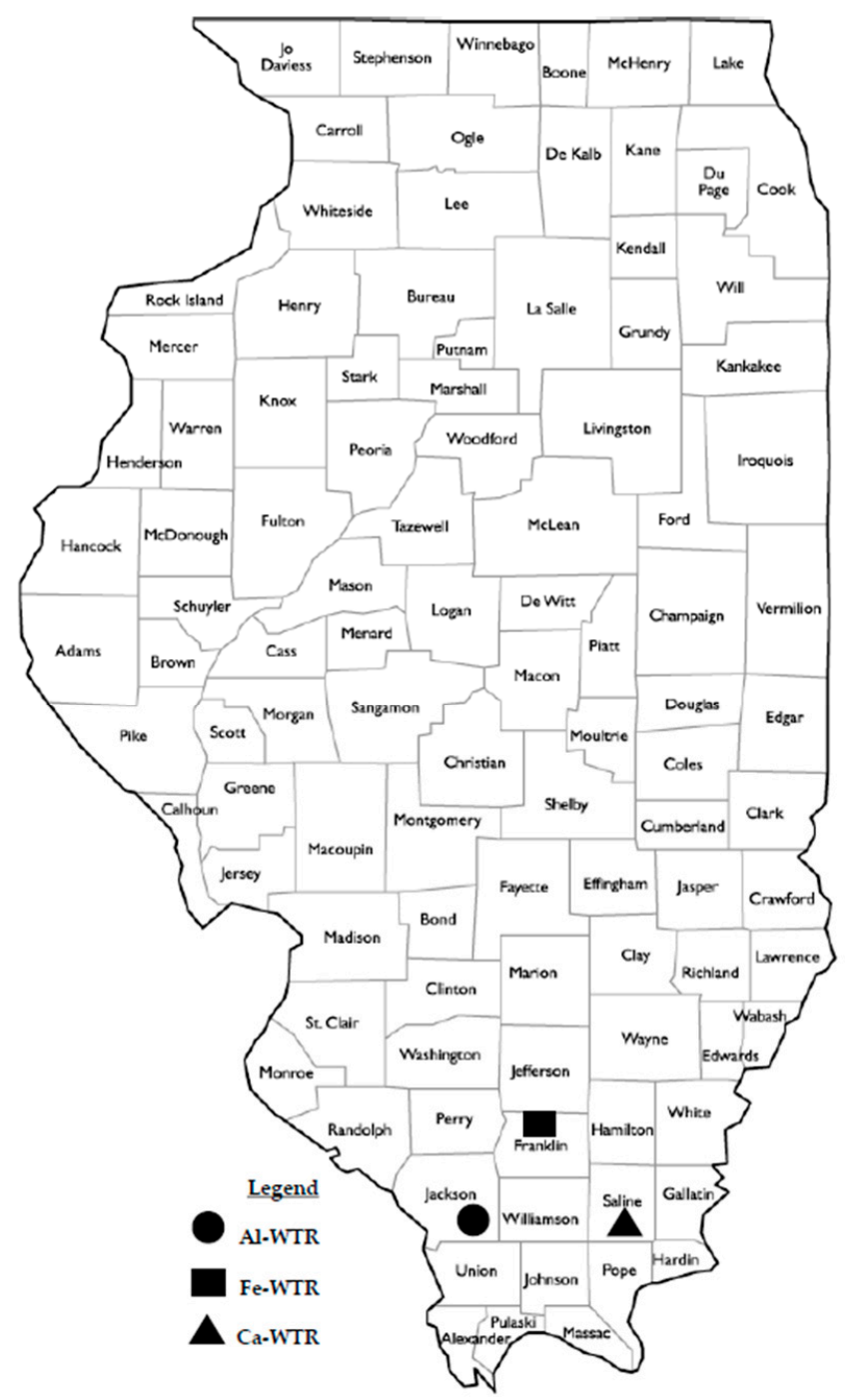

Figure 1. County map of the State of Illinois: the counties where water treatment residuals (WTRs) were sampled, are indicated. 
For identification purposes, the alum, ferric salt/lime, and lime residues were represented by the dominant constituent element as Al-WTR, Fe-WTR, and Ca-WTR, respectively. The sampling and characterization were performed during the summer of 2015. The collected individual samples were air-dried at a room temperature of $\sim 25^{\circ} \mathrm{C}$, on paper laid on a clean concrete floor, prior to the subsequent chemical analysis. This was because oven drying of the samples at temperatures higher than $49^{\circ} \mathrm{C}$ could possibly affect the results of the extractable cation analysis [31]. The air-dried WTR samples were crushed, homogeneously mixed, and sieved through a $2 \mathrm{~mm}$ mesh (as shown in Figure 2) for storage and subsequent analysis. The samples were stored at an ambient temperature and the $\mathrm{pH}$ and electrical conductivity (EC) analysis were conducted not more than 4 weeks after sampling. The nutrient and other elemental analyses were conducted within 8 weeks of sampling.

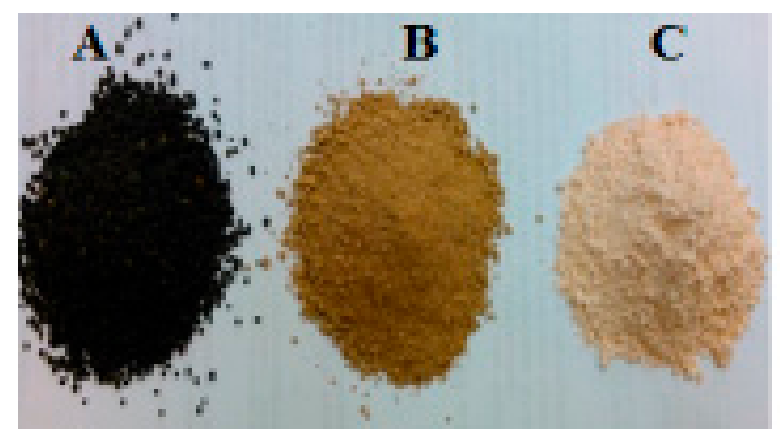

Figure 2. (A) Dry Aluminum (Al)-WTR; (B) Iron (Fe)-WTR; and (C) Calcium (Ca)-WTR.

\subsection{Analytical Methods}

The dry WTR samples were analyzed for total ionic strength or electrical conductivity (EC), and $\mathrm{pH}$ using calibrated probes connected to a PASCO advanced water quality sensor (PS-2230). The $\mathrm{pH}$ was measured in deionized (D.I.) water using a two-point calibrated Pasco $\mathrm{pH}$ probe (PS-2102) with an accuracy of \pm 0.1 and resolution of 0.01. A WTR:D.I. water ratio of 1:2.5 $(w / v)$ was used as an extract. The mixture was stirred with a glass rod and the WTR was allowed to settle during the $45 \mathrm{~min}$ contact time before measuring from the supernatant. The EC of the WTR samples was measured with a Pasco conductivity probe (10X PS-2571), in a 1:5 (w/v) WTR:D.I. water solution at $25^{\circ} \mathrm{C}$, in order to determine the concentrations of salts [32].

The specific gravity of the WTR particles was determined with a standard test method for solids, using a water pycnometer (ASTM D 854-00), where the mass of a solid sample was determined by weighing, and the volume was determined by calculation from the mass and density of water displaced by the sample. A high-resolution particle size analysis of the fine-grain WTR samples was performed by laser diffractometry using the patented Microtrac ${ }^{\circledR}$ Tri-Laser Technology Bluewave particle size analyzer. The particle size classification was based on the Wentworth scale [33]. Extractable cations in the WTR samples were measured by the neutral ammonium acetate $\left(\mathrm{NH}_{4} \mathrm{OAC}\right)$ extraction method in order to assess the amount of plant available potassium, magnesium, calcium, and sodium in each sample. Although the $\mathrm{Na}$ availability was generally not essential for plant growth [34], the test was required in order to diagnose sodic and sodic-saline conditions of the soil samples. The method involved shaking the sample with a solution of $1 \mathrm{M} \mathrm{NH}_{4} \mathrm{OAc}$, which was adjusted to a neutral $\mathrm{pH}$, after which the filtrate was analyzed for $\mathrm{K}^{+}, \mathrm{Na}^{+}, \mathrm{Ca}^{2+}$, and $\mathrm{Mg}^{2+}$ by inductively coupled argon plasma (ICAP) detection. The cation exchange capacity (CEC), which measures the quantity of readily exchangeable cations that neutralize negative charges in the soil, was then estimated through the summation of the extractable cations. It must, however, be mentioned that errors are most likely to occur in the "sum of bases" method, which is used for calculating the CEC of alkaline materials like WTRs, which contain significant amounts of free $\mathrm{CaCO}_{3}$ and high concentrations of soluble $\mathrm{Ca}$. The release of calcium carbonate from the WTRs into the ammonium acetate solution limited the saturation 
of exchange sites by the ammonium ion, therefore, result in artificially low CEC. Hence, the reported values were treated as indexes of the relative minimum CEC rather than the quantitative measures of CEC in WTR.

The organic matter content ( $\%$ of OM) in WTR samples was determined by the loss on ignition (LOI) method by comparing the weight difference before and after combustion in a furnace. The representative samples that were finer than $2 \mathrm{~mm}$ were oven-dried at $105^{\circ} \mathrm{C}$ for $24 \mathrm{~h}$. The oven-dried samples were then weighed into crucibles and combusted for $1 \mathrm{~h}$ at $375^{\circ} \mathrm{C}$. The representative samples of the WTRs were analyzed for concentrations of RCRA metals and other metals, including $\mathrm{Cu}, \mathrm{Mn}$, $\mathrm{Ni}, \mathrm{Zn}, \mathrm{Co}, \mathrm{Li}, \mathrm{Fe}$, and $\mathrm{Al}$, by inductively coupled plasma mass spectrometry (ICP-MS). Furthermore, $-0.5 \mathrm{~g}$ samples were digested in aqua regia (a mixture of $\mathrm{HNO}_{3}$ and $\mathrm{HCl}$, optimally in a 1:3 molar ratio) at about $90{ }^{\circ} \mathrm{C}$ in a microprocessor controlled digestion block for $2 \mathrm{~h}$. The suite of metal analysis was performed by the Acme Labs (Bureau Veritas) commercial laboratory (http://acmelab.com). The standard deviation for the repeated analysis was consistently $<8 \%$ of the mean of most of the elements, except for $\mathrm{Hg}, \mathrm{Ag}, \mathrm{Ni}, \mathrm{Li}$, and $\mathrm{Al}(15-28 \%)$.

The determination of plant available micronutrients, including $\mathrm{Zn}, \mathrm{Mn}, \mathrm{Fe}$, and $\mathrm{Cu}$, were determined by extraction with diethylenetriaminepentaacetic acid (DTPA), a chelating compound [35] using ICAP detection. Boron was extracted using DTPA/sorbitol with ICAP detection. Percentage carbon and percentage nitrogen were determined by combustion, using a Thermo Scientific Delta V Plus isotope ratio mass spectrometry (IRMS) with a dual inlet and Conflo IV interface connected to a Costech 4010 elemental analyzer (EA) at Southern Illinois University analytical chemistry laboratory. The water soluble, inorganic nitrate-nitrogen $\left(\mathrm{NO}_{3}-\mathrm{N}\right)$ was determined by the reduction of nitrate in a segmented flow analysis (SFA) system. The phosphorus in the WTRs was determined after the Olsen-or bicarbonate-and the Bray extraction tests. In the Olsen technique, the dry WTR samples were extracted with a weak solution of $\mathrm{NaHCO}_{3}$, which was adjusted to $\mathrm{pH} 8.5$, whereas the Bray extraction test used a mild acid with ammonium fluoride, followed by colorimetric detection. Technically, the Olsen and Bray approaches only extracted a portion of total sample P, and were therefore treated as indexes of relative WTR sample P availability, rather than the quantitative measures of $\mathrm{P}$ content [36].

The bulk mineralogical data of randomly oriented WTR powder samples was (e.g., the authors of [37] described using X-ray diffraction [XRD] patterns from a Rigaku Ultima IV X-ray diffractometer with $\mathrm{CuK} \alpha$ radiation) and intensity data were collected in the $2 \theta$ angular range of $2^{\circ}-60^{\circ}$ with a scanning step of $0.02^{\circ}$, using $\mathrm{Cu}-\mathrm{K} \alpha$ radiation. The identification of mineral phases was conducted by comparing calculated d-spacing values with published crystal structure data [38].

\section{Results and Discussion}

\subsection{Physicochemical Analysis}

The analytical results of the selected properties of the WTR samples are shown in Table 1. The measured $\mathrm{pH}$ of WTRs ranged from 7.0 to 9.1. Specifically, the Ca-WTR and Fe-WTR samples were higher than typically reported $\mathrm{pH}$ ranges of WTRs mostly between 5.10 and $8.00[11,39,40]$. The alkaline $\mathrm{pH}$ of the Ca-WTR ( $\mathrm{pH} \sim 9.1$ ) and Fe-WTR ( $\mathrm{pH} \sim 8.4$ ) produced a high acid neutralizing potential. The effect of drying on the particle size characteristics of the collected Al-WTR sample, in particular, was found to be significant, as dried samples formed hard, stable, and coarse aggregates. Hence, the particle sizes of the Al-WTR were not determined, as it would not have been representative. The textural analysis (shown in Figure 3) of Ca- and Fe-WTRs showed $76.1 \%$ and $75 \%$ of silt, respectively, in the Wentworth grain size range of $0.39-63$ microns. The Ca-WTR recorded $12.5 \%$ fine sand particles, which was more than Fe-WTR, which recorded 5.0\%. Since coagulants enhanced settling of fine particles out of the solution, the residues were expected to exhibit high clay and silt fractions. However, fine particles coagulated into larger stable aggregates (flocs), which became stable and coarse once dried, through the influence of interparticle bonds. The particle size analysis was not performed for 
the Al-WTR, because of the formation of a coarse texture when air-dried although, it was likely that the dried Al-WTR would disintegrate into its constituent fractions when in contact with water for a longer period. Such scenarios might lead to the clogging of the soils pores and result in reduced hydraulic conductivity and water retention in soils that were amended with Al-WTR. According to Titshall and Hughes [11], this might increase the reactive sites for the release of potentially toxic elements from the WTR into the soils systems.

Table 1. Relevant properties of three Southern Illinois water treatment residues (WTRs).

\begin{tabular}{ccccccc}
\hline \multirow{2}{*}{ WTR Sample } & \multirow{2}{*}{$\mathbf{p H}($ Std. Units) } & \multirow{2}{*}{ EC $(\mu \mathrm{s} / \mathrm{cm})$} & \multirow{2}{*}{ Particle Density $(\mathrm{g} / \mathrm{cc})$} & \multicolumn{3}{c}{ Soil Texture (\%) } \\
\cline { 5 - 7 } & & & & Fine Sand & Silt & Clay \\
\hline Al-WTR & 7.00 & 412.0 & 1.54 & und & und & und \\
Ca-WTR & 9.10 & 321.3 & 2.47 & 12.5 & 76.5 & 11.0 \\
Fe-WTR & 8.40 & 675.5 & 2.32 & 5.0 & 75.0 & 20.0 \\
\hline
\end{tabular}

Potential of hydrogen $(\mathrm{pH})=1: 2.5$ (w:v; soil:water); electrical conductivity $(\mathrm{EC})=1: 5$ (w:v; soil:water); und-undetermined; Al-WTR-Aluminum-WTR; Fe-WTR-Iron-WTR; Ca-WTR-Calcium-WTR.

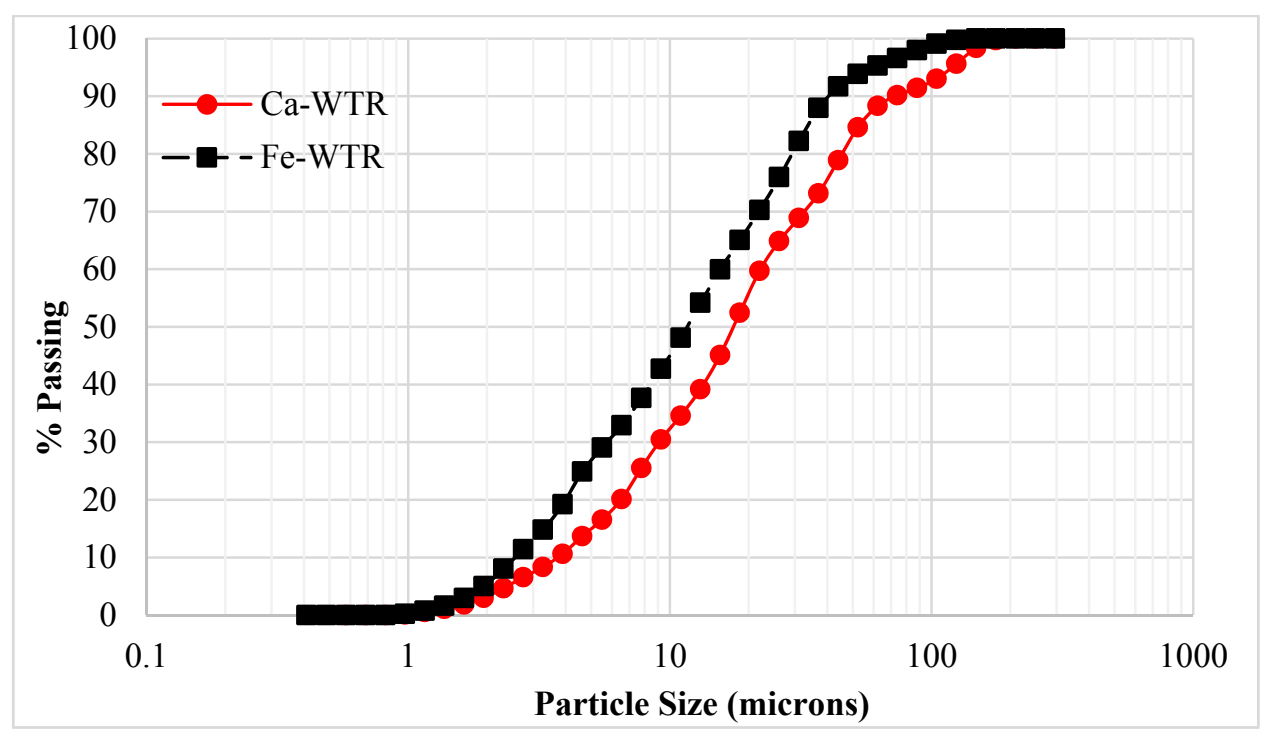

Figure 3. Particle size distribution of WTRs.

The EC of the WTRs $(0.32-0.67 \mathrm{dS} / \mathrm{m})$ were within the reported ranges of $0.22-1.10 \mathrm{dS} / \mathrm{m}$ for 17 Oklahoma WTRs [41]. The samples were also analyzed for soluble salts; a measure of the salt concentration that the WTRs could induce in a solution. Soluble salts in the WTRs were between 0.5 and $0.9 \mathrm{dS} / \mathrm{m}$, with the Fe-WTR indicating the highest, primarily as a result of the ferric salt coagulants that were used in the water treatment process at the plant, which produced the Fe-WTR. However, the effect of salinity could be considered to be negligible if the analysis of soluble salts was less than $1.0 \mathrm{dS} / \mathrm{m}$. It is important to ensure that the amendment of WTRs to soil does not result in soluble salts that exceed $1.0 \mathrm{mmhos} / \mathrm{cm}$, so as to avoid the effects on salt-sensitive plants, or $2.0 \mathrm{dS} / \mathrm{m}$, at which salt-tolerant plants would be required. The WTRs, therefore, did not pose potential problems that would have compromised plant health and yield when it was applied to soils.

\subsection{Total Metal Analysis}

The quantitative determination of the major elemental composition of the WTRs is shown in Table 2. There were significant variabilities in the chemical composition of the WTRs, as was suggested. The analytical results of the metal concentrations of the three WTR samples indicated Ba and As as the dominant regulated RCRA 8 metals, whereas $\mathrm{Hg}$ and $\mathrm{Ag}$ were found in negligible amounts. The 
significant abundance of heavy metals in the WTRs included $\mathrm{Fe}, \mathrm{Mn}, \mathrm{Al}$, and $\mathrm{Cu}$. Comparatively, the concentrations of heavy metals in the Ca-WTR was found to be the lowest. Trace elements of some rare earth elements were also observed, including $\mathrm{La}, \mathrm{Sc}, \mathrm{Nb}, \mathrm{Y}$, and $\mathrm{Ce}$, in all of the WTRs.

Table 2. Total heavy and trace metal concentrations in the water treatment residue samples \pm S.D. (standard deviation). RCRA-resource conservation and recovery act.

\begin{tabular}{|c|c|c|c|c|c|c|c|c|}
\hline \multirow{2}{*}{$\begin{array}{c}\begin{array}{c}\text { Metals } \\
\text { (RCRA) }\end{array} \\
\text { WTR sample }\end{array}$} & \multicolumn{8}{|c|}{ Mean Concentration in $\mathrm{mg} / \mathrm{kg} \pm$ S.D. } \\
\hline & As & $\mathrm{Ba}$ & $\mathrm{Cd}$ & $\mathrm{Cr}$ & $\mathrm{Pb}$ & Se & $\mathrm{Hg}$ & $\mathrm{Ag}$ \\
\hline Al-WTR & $69.60 \pm 3.25$ & $164 \pm 6.01$ & $0.09 \pm 0.01$ & $5.35 \pm 0.07$ & $5.84 \pm 0.12$ & $1.45 \pm 0.21$ & $0.02 \pm 0.00$ & $0.03 \pm 0.00$ \\
\hline Ca-WTR & $18.10 \pm 0.28$ & $96.10 \pm 1.76$ & $0.18 \pm 0.01$ & $2.00 \pm 0.14$ & $0.36 \pm 0.02$ & $0.20 \pm 0.00$ & $<0.01$ & $0.01 \pm 0.00$ \\
\hline Fe-WTR & $9.15 \pm 0.21$ & $126 \pm 2.75$ & $0.12 \pm 0.01$ & $20.1 \pm 0.77$ & $7.04 \pm 0.12$ & $0.45 \pm 0.07$ & $0.01 \pm 0.01$ & $0.03 \pm 0.00$ \\
\hline Metals & \multicolumn{5}{|c|}{ Mean concentration in $\mathrm{mg} / \mathrm{kg} \pm$ S.D. } & \multicolumn{3}{|c|}{$(\%)$} \\
\hline WTR sample & $\mathrm{Cu}$ & $\mathrm{Mn}$ & $\mathrm{Ni}$ & $\mathrm{Zn}$ & Co & $\mathrm{Ca}$ & $\mathrm{Fe}$ & $\mathrm{Al}$ \\
\hline Al-WTR & $46.20 \pm 2.36$ & $5283 \pm 42.42$ & $16.70 \pm 0.35$ & $47.30 \pm 3.74$ & $3.65 \pm 0.21$ & $0.36 \pm 0.01$ & $0.58 \pm 0.00$ & $>10.0$ \\
\hline Ca-WTR & $1.38 \pm 0.84$ & $203 \pm 2.12$ & $0.60 \pm 0.14$ & $9.00 \pm 0.00$ & $0.85 \pm 0.07$ & $33.00 \pm 0.51$ & $0.61 \pm 0.01$ & $0.04 \pm 0.01$ \\
\hline Fe-WTR & $18.20 \pm 0.57$ & $2639 \pm 40.30$ & $14.60 \pm 0.00$ & $26.50 \pm 0.00$ & $5.85 \pm 0.21$ & $16.00 \pm 0.20$ & $2.92 \pm 0.06$ & $0.63 \pm 0.01$ \\
\hline Metals & \multicolumn{8}{|c|}{ Mean concentration in $\mathrm{mg} / \mathrm{kg} \pm$ S.D. } \\
\hline WTR sample & Th & $\mathrm{La}$ & Ga & Sc & $\mathrm{Nb}$ & $\mathrm{Zr}$ & $\mathrm{Y}$ & $\mathrm{Ce}$ \\
\hline Al-WTR & $0.85 \pm 0.07$ & $3.60 \pm 0.14$ & $13.30 \pm 0.49$ & $0.90 \pm 0.07$ & $0.30 \pm 0.00$ & $3.40 \pm 0.00$ & $3.00 \pm 0.12$ & $7.50 \pm 0.49$ \\
\hline Ca-WTR & $0.10 \pm 0.00$ & $0.80 \pm 0.00$ & $0.20 \pm 0.00$ & $0.50 \pm 0.07$ & $0.10 \pm 0.00$ & $1.10 \pm 0.00$ & $1.40 \pm 0.04$ & $1.00 \pm 0.00$ \\
\hline Fe-WTR & $2.15 \pm 0.07$ & $7.55 \pm 0.07$ & $1.90 \pm 0.00$ & $0.17 \pm 0.00$ & $0.30 \pm 0.00$ & $3.40 \pm 0.14$ & $5.30 \pm 0.14$ & $16.60 \pm 0.21$ \\
\hline
\end{tabular}

\subsection{Toxicity Analysis}

The total concentrations of the Resource Conservation and Recovery Act (RCRA) metals, especially As and Ba were significant for the WTRs. However, only a fraction of the total concentration was estimated to have leached from the WTRs. The Toxicity Characteristic Leaching Procedure (TCLP) estimate was used to predict whether the hazardous components of the WTR were likely to leach out of the waste, under simulated landfill conditions, becoming a threat to public health or the environment. The results showed in Table 3 indicated that, although significant amounts of the RCRA 8 metals could be released from the WTRs, none was above the allowed USEPA Part 503 concentration limits. However, the release of significant amounts of As, especially from the Al-WTR, raised concerns for land application. Arsenic (As) could be found in the atmosphere, soils, and rocks, and natural waters, among other sources. It is mostly introduced in the environment through natural processes, such as weathering reactions and biological activity, as well as through anthropogenic routes, including mining, combustion of fossil fuels, pesticides, herbicides, and the use of arsenic as an additive to animal feed. All drinking water treatment technologies that remove arsenic create residuals with concentrated arsenic and other co-occurring contaminants. The comparatively high concentration of As in the Al-WTR, which treated water from a reservoir, might have been because of obvious point sources of As contamination within the catchment area, such as crop, livestock, and poultry farms. However, the observed concentration in the Fe-WTR might have come from similar sources to the Al-WTR, since the facility treated water from a lake close to many farms. Observed concentrations of As in the Ca-WTR might have also been a result of transport from a nearby abandoned mine close to the Saline Valley water treatment facility. 
Table 3. Toxicity Characteristic Leaching Procedure (TCLP) estimates of RCRA 8 metals in WTR.

\begin{tabular}{ccccccccc}
\hline RCRA Metal & As & Ba & Cd & Cr & Pb & Hg & Se & Ag \\
\hline Waste Number & D004 & D005 & D006 & D007 & D008 & D009 & D010 & D011 \\
\hline WTR sample & & \multicolumn{7}{c}{$\mathrm{mg} / \mathrm{kg}$} \\
\hline Al-WTR & 3.48 & 8.19 & 0.005 & 0.268 & 0.292 & 0.0011 & 0.073 & 0.0015 \\
Ca-WTR & 0.91 & 4.80 & 0.009 & 0.100 & 0.018 & 0.0003 & 0.010 & 0.0003 \\
Fe-WTR & 0.46 & 6.31 & 0.006 & 1.013 & 0.352 & 0.0007 & 0.022 & 0.0014 \\
US EPA Limits & 5.0 & 100.0 & 1.0 & 5.0 & 5.0 & 0.2 & 1.0 & 5.0 \\
\hline
\end{tabular}

\subsection{Analysis of WTR Nutrient Compositions}

The percent organic matter measured the amount of plant and animal (organic) residue in the WTRs. Since the Ca-WTR was produced as a byproduct of groundwater treatment, there was very low amounts of coagulated organic sediments and, hence, recorded the least organic matter content of $1.3 \%$. The Al-WTR indicated a very high organic matter content and was less dense, showing a particle density of $1.54 \mathrm{~g} / \mathrm{mL}$ compared with the Ca-WTR of $2.47 \mathrm{~g} / \mathrm{mL}$ and Fe-WTR of $2.32 \mathrm{~g} / \mathrm{mL}$. Organic matter served as a reserve for many essential nutrients, especially nitrogen, which was made available to the plant through bacterial activity. The CEC of WTR indicated the capability of WTRs to hold cationic nutrients, such as $\mathrm{K}, \mathrm{Mg}$, $\mathrm{Ca}$, and $\mathrm{Na}$. The measure of $\mathrm{CEC}$ was dependent on the concentration of the exchangeable divalent $\mathrm{Mg}$ and $\mathrm{Ca}$, and on the amount of clay minerals and organic matter that were present. Exchangeable Ca of $8.54 \mathrm{meq} / 100 \mathrm{~g}$ in Ca-WTR was comparable to the concentration of $8.47 \mathrm{meq} / 100 \mathrm{~g}$ in Fe-WTR, however, it was lower in the Al-WTR. Extractable K and $\mathrm{Na}$ were low for all of the WTRs. The Ca and Mg resulted in the CEC of the WTRs, which ranged from 4.6 to $16.2 \mathrm{meq} / 100 \mathrm{~g}$ WTR. The Ca:Mg ratio of the Al-, Ca-, and Fe-WTRs were 1:7, 1:2, and 1:1.5 (meq basis), respectively. Although the Ca-WTR showed very high concentrations of total Ca (Table 2), it was clear that the Ca was not in a readily available form, as suggested in Table 4 . In all of the WTRs, however, extractable $\mathrm{Ca}$ and $\mathrm{Mg}$ were in adequate plant available concentrations.

Table 4. Nutrient concentrations of the water treatment residues.

\begin{tabular}{|c|c|c|c|c|}
\hline \multicolumn{2}{|c|}{ Property } & Al-WTR & Ca-WTR & Fe-WTR \\
\hline \multicolumn{2}{|c|}{ Total sulfur (mg/kg) } & 99.00 & 46.00 & 189 \\
\hline \multicolumn{2}{|c|}{ Total C (\%) } & UND & 1.68 & 1.01 \\
\hline \multicolumn{2}{|c|}{ Total N (\%) } & UND & $<0.03$ & 0.14 \\
\hline \multicolumn{2}{|c|}{ Organic Matter (\%) } & 34.90 & 1.30 & 3.10 \\
\hline \multicolumn{2}{|c|}{$\mathrm{NO}_{3}-\mathrm{N}(\mathrm{mg} / \mathrm{kg})$} & 5.00 & 2.00 & 1.00 \\
\hline \multirow{3}{*}{ Phosphorus (mg/kg) } & Weak Bray & 12.00 & 1.00 & 1.00 \\
\hline & Strong Bray & 42.00 & 2.00 & 2.00 \\
\hline & Olsen Bicarbonate & 6.00 & 10.0 & 13.00 \\
\hline \multicolumn{2}{|c|}{ Soluble salts (mmhos/cm) } & 0.50 & 0.30 & 0.90 \\
\hline \multirow{4}{*}{$\begin{array}{l}\text { Exchangeable cations } \\
\qquad(\mathrm{meq} / 100 \mathrm{~g})\end{array}$} & $\mathrm{K}$ & 0.09 & 0.04 & 0.12 \\
\hline & $\mathrm{Mg}$ & 0.52 & 4.50 & 7.37 \\
\hline & $\mathrm{Ca}$ & 3.65 & 8.54 & 8.47 \\
\hline & $\mathrm{Na}$ & 0.37 & 0.11 & 0.17 \\
\hline \multicolumn{2}{|c|}{ Cation exchange capacity (meq/100 g) } & 4.60 & 13.20 & 16.20 \\
\hline
\end{tabular}

UND-Undetermined. 
Although percentage $\mathrm{C}$ in both the Fe- $(1.01 \%)$ and Ca-WTR $(1.68 \%)$ were relatively low, it did not deviate significantly from the reported values of similar samples. Basta [40] reported values ranging from $0.8 \%$ to $6.5 \%$, and the authors [41] reported values from 1.7 to $14.9 \%$. A total organic carbon content of 3.0\% was recorded by Elliott et al. [42] from a composition analysis of WTRs from seven Pennsylvania water treatment facilities. Percentage N was $0.14 \%$ for the Fe-WTR and did not exceed $0.03 \%$ of the Ca-WTR. Nitrate-N, which used to indicate direct plant available nitrogen, was low, ranging between 1.0 and $5.0 \mathrm{mg} / \mathrm{kg}$ (loading rate of 2 to $9 \mathrm{lbs} / \mathrm{ac}$ ). Generally, plant available nitrogen, phosphorus, and potassium were found to be low in the WTRs. However, when they are amended into nutrient-poor soils, they might have been able to help to improve soil conditions, enhancing plant growth.

\subsection{Influence of WTR Application on Phosphorus}

Many research findings had indicated that WTR application might have presented many disadvantages, because of the potential adsorption of plant-available $\mathrm{P}$, which might have resulted in reduced yields of maize [43], tomato [44], and more recently, wheat [45]. However, other researchers had also contrasted earlier findings of WTR adsorption of available P levels in amended soils [29]. Geertsema et al. [46] found no significant differences in bioavailable and total P concentrations, following 30 months of WTR application for growing pine. Mahdy et al. [47] also applied WTR to three types at varying field equivalent rates. Although they found decreased $\mathrm{P}$ concentrations at higher rates of WTR ( $>67 \mathrm{Mg} / \mathrm{ha}$ ) in calcareous and clay soils, the P concentration continued to increase proportionally with increased application rates. Although much interest was expressed in studying the impact of WTR application on soil P, with respect to crop productivity, previous researchers concluded differently.

\subsection{Mineralogical Analysis}

The identification of mineral phases is shown in Figure 4. Generally, the samples showed the presence of clay and non-clay minerals, as well as a significant amount of amorphous materials. The dominant minerals in the WTRs samples were mostly calcite, quartz, and feldspar. Although it was not recorded in the Al-WTR, calcite was the most dominant mineral in the Fe-WTR and, obviously, the Ca-WTR, which resulted from the lime that was used at the respective treatment facilities. The presence of quartz in the WTR samples was possibly a result of the varying amounts of suspended sand particles that were removed by the coagulants. The Ca-WTR, which was collected from the facility that treated groundwater, did not show any quartz in the XRD spectra. However, the Al- and Fe-WTRs that were collected from the facilities that treated surface water showed various peaks for quartz. Aside from the amounts of quartz in the Al-WTR, the XRD pattern consisted largely of disordered materials, possibly amorphous hydrous metal oxides- $\mathrm{Al}(\mathrm{OH})_{3}$ from the reaction of alum in water with bicarbonate-and organic fractions. This finding was consistent with Titshall and Hughes [11], and Ippolito et al. [48]. A similar reaction was reported for iron-salt coagulants. The less-crystalline nature of the WTRs, the presence of metal (hydr)oxides, and their porous structure were major characteristics that influenced their metal ion adsorption capacities. Hence, WTRs could be presented as competitive options for remediating heavy metal contaminated aqueous solutions and soil. 


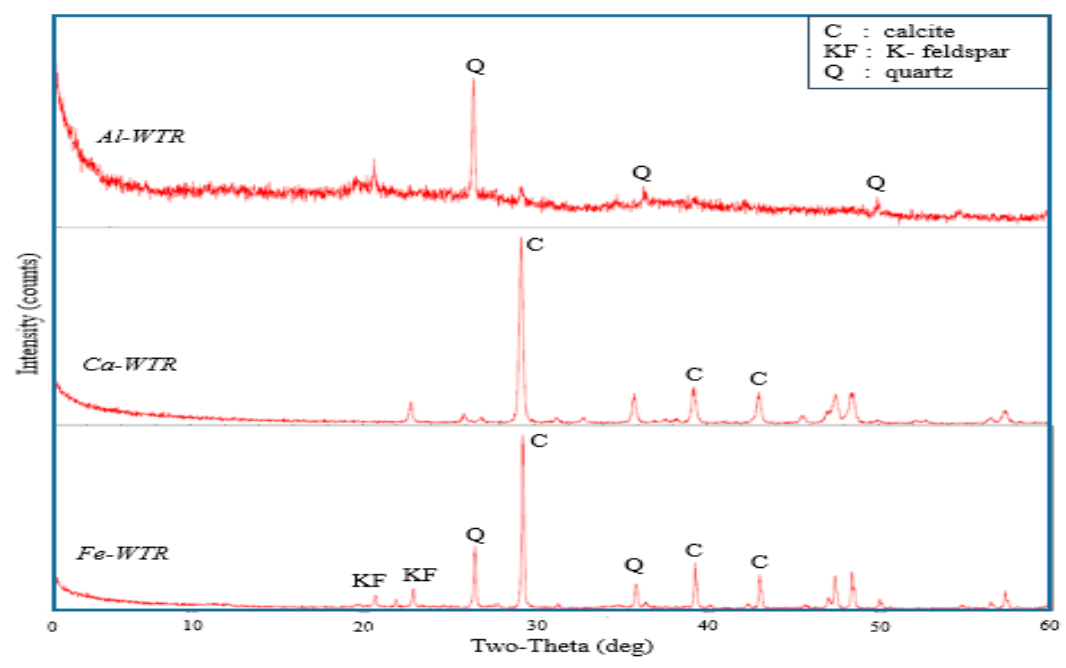

Figure 4. XRD patterns of the WTRs.

\subsection{DTPA Extractable Micronutrient}

The use of a total element content did not give the correct indication of the toxicity of waste materials because it did not reflect the labile or available the fractions. Hence, the DTPA extracted micronutrients were used to assess the ease of the release of some heavy metals and boron under acidic conditions. The DTPA concentrations, shown in Figure 5, raised some concerns with regards to the relatively high exchangeable $\mathrm{Mn}$ and Fe in the WTRs. Although both the Fe- and Al-WTRs showed elevated concentrations of exchangeable Mn compared with the Ca-WTR, the Mn concentration of the Al-WTR was exceptionally high. Manganese was considered an essential plant nutrient that helped in metabolic processes, such as photosynthesis, and as an enzyme antioxidant-cofactor [49]. The inadequate or excess manganese that was available to plants could have affected various metabolic processes. Manganese toxicity was mainly observed through the reduction of biomass and photosynthesis. Bioavailability of $\mathrm{Mn}$ in soils was influenced by soil $\mathrm{pH}$ and redox conditions [50]. The most available form- $\mathrm{Mn}$ (II) in the soil for plants-became more mobile at an acidic $\mathrm{pH}$, whilst the enhanced Mn adsorption onto soil particles decreased its availability to plants [51] at a higher soil $\mathrm{pH}$. In that regard, the high $\mathrm{pH}$ of the WTRs, particularly the Ca- and Fe-WTRs, when amended with soil at optimum amounts, might have helped to immobilize excess Mn, whilst creating a near-neutral soil $\mathrm{pH}$ for adequate plant growth. Achieving this would have maintained the favorability of the Fe- and Ca-WTRs for safe land applications. Under similar conditions, the direct use of the Al-WTR would present some challenges, primarily because of its comparatively low acid neutralizing.

The concentration of the DTPA exchangeable Fe was studied in the WTRs. Again, the Fe-WTR released considerable amounts of exchangeable Fe, followed by the Ca-WTR and Al-WTR, which released the least amount under the test condition. This suggested that an appreciable amount of the total Fe concentration in the Ca- and Fe-WTRs could have been made available to plants under acidic conditions. Excess available plant Fe might have been injurious to plants' health and growth (Peña-Olmos et al., 2014), although the severity of Fe toxicity and yield had not been established. An identifiable symptom linked to Fe (II), included browning or yellowing of the leaves and subsequent growth inhibition, which might have resulted in reduced productivity in some crops [52]. Since excess iron toxicity was associated with low soil $\mathrm{pH}$ values [53], the high $\mathrm{pH}$ of the Ca- and Fe-WTRs might have been able to maintain a near neutral $\mathrm{pH}$, in order to reduce the mobility of the Fe ions in soil.

The DTPA extracted $\mathrm{Cu}$ concentrations in the Fe-WTR were slightly higher compared with the concentrations in the Ca- and Al-WTRs. There was an estimated $109 \%$ difference between the $\mathrm{Cu}$ concentration in the Fe-WTR, and the Ca-WTR and was about 78\% higher than in the Al-WTR. This increment could have possibly been because of the composition of the Fe-salt that was used for the 
water purification process. There was, however, very little variation in B and Zn concentrations in the WTRS. Irrespective of the presented possibilities of the WTRs to counteract the potential releases of high levels of Fe and $\mathrm{Mn}$, the release of metals under sustained acidic conditions represented a major concern, which needed proper monitoring prior to applications. Although it was not an essential element for either plants or animals, aluminum (Al) was highly abundant in the WTRs in the total concentrations. Research indicated that $\mathrm{Al}$ toxicity was related to the amount of $\mathrm{A} 1^{3+}$ in the solute solution [54]. The test results from Melich-3 and other stronger extractants, such as DTPA, however, did not have a strong relationship to $\mathrm{Al}^{3+}$. Furthermore, the forms of $\mathrm{Al}$ that were extracted by large volumes of salt solutions were not necessarily equivalent to available forms in the soil, because the $\mathrm{Al}$ was well mixed to form precipitation with ligands, such as fluoride $(\mathrm{F})$, sulfate $\left(\mathrm{SO}_{4}{ }^{2+}\right)$, and oxalate and, hence, became non-toxic [54]. Therefore, the $\mathrm{pH}$ of the WTRs was probably the single most important factor that was considered to control the amount of $\mathrm{A} 1^{3+}$ in the WTR solution. The amount of soluble $\mathrm{Al}$ increased as the $\mathrm{pH}$ dropped below $\mathrm{pH}$ 5.0. The high $\mathrm{pH}$ of the WTRs and their high neutralizing capability meant that, when amended to acidic soil to create $\mathrm{pH}$ conditions above 5.0, the $\mathrm{Al}$ toxicity would rarely become a problem.

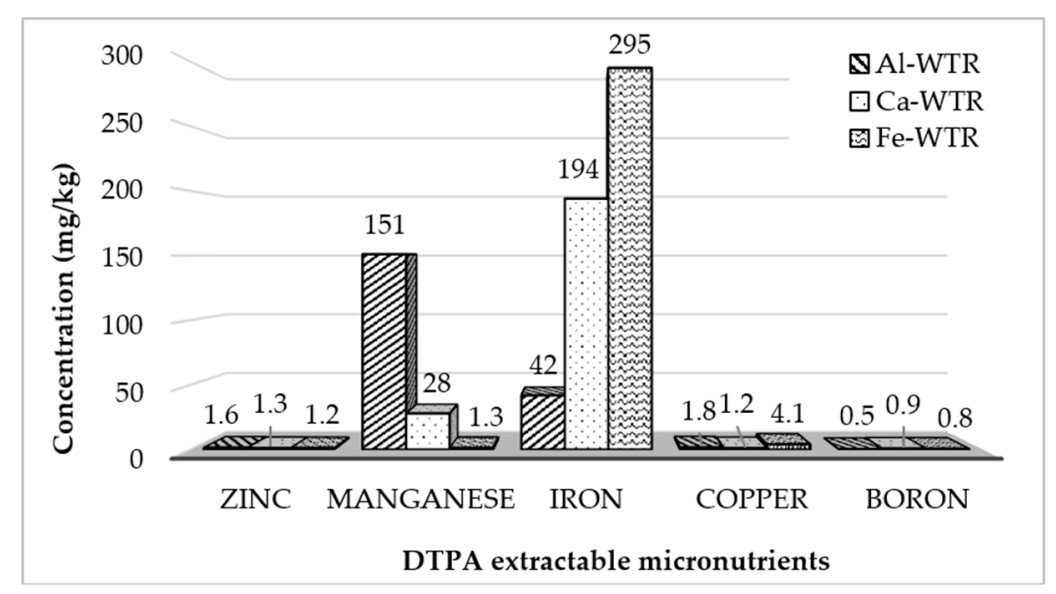

Figure 5. Diethylenetriaminepentaacetic acid (DTPA) extractable micronutrients $(\mathrm{mg} / \mathrm{kg})$ in WTRs.

\section{Concluding Remarks}

This work has demonstrated the favorable potential for the beneficial reuse of WTR through composition analysis of relevant physical, chemical, agronomic, and mineralogical properties. It was also confirmed that the properties of the WTRs were mostly site-specific, owing to the significant variabilities in the properties, which were mostly influenced by the source water quality and type of coagulant of softener that was used.

The qualitative determination of the major elements showed varying acceptable concentrations of RCRA 8 metals in the WTRs. Nevertheless, the concentrations of DTPA extractable Mn and Fe raised concerns of possible contamination under sustained acidic conditions, which would require frequent monitoring when applied. The WTRs, however, showed an adequate capability to supply the relevant plant nutrients such as $\mathrm{Zn}, \mathrm{Ca}, \mathrm{Mg}, \mathrm{K}, \mathrm{S}, \mathrm{Cu}$, and $\mathrm{Fe}$, although readily available concentrations of $\mathrm{NO}_{3}-\mathrm{N}, \mathrm{P}$, and $\mathrm{K}$ were generally low. The $\mathrm{X}$-ray diffraction analysis of the samples showed a significant amount of amorphous phases, mostly metal hydroxides. The Ca-WTR was almost entirely composed of calcite, whilst the Al-WTR contained mostly quartz. The Fe-WTR contained a mix of calcite and quartz. The minor occurrence of clay minerals in mixed layers was observed from the diffractograms. In retrospect, the alkaline nature, relatively high CEC, and satisfactory concentrations of heavy metals, as well as the RCRA 8 metals of the WTRs, suggested the potential for safe and beneficial land application. The generally amorphous and porous nature of the WTRs also suggested good metal ion adsorption capabilities in soil and aqueous solution. 
The authors recommended, therefore, that although the land application of the WTRs was proven to be feasible, a prior background physicochemical analysis of the application site soils should be conducted in order to optimize the rate of the WTR application. This would be helpful so as to avoid the introduction of excess elements, which may negatively affect plant growth at contaminable concentrations in the soil. In this regard, the authors ascertain that the ideal land application of WTRs may be best achieved on non-food chain crops, mine reclamation areas, and forest areas. Future research needs to be conducted in order to expand on the number of WTRs in the region and beyond, in order to ascertain their appropriateness for soil and water remediation, and other beneficial uses. The evaluation of WTR adsorption in soil and water is also recommended.

Author Contributions: Conceptualization: X.M.; Methodology: M.M., X.M., L.A.A., S.K., J.L., R.G. and M.P.; Data Analysis: M.M., X.M., L.A.A., S.K., J.L., R.G. and M.P.; Resources: M.M., X.M., S.K.; Writing: Original Draft Preparation-L.A.A.; Writing: —Review \& Editing: M.M., L.A.A., J.L. and S.K.; Supervision: M.M., X.M., S.K., J.L.; Project Administration: M.M. and X.M.; Funding Acquisition: X.M.

Funding: This research was funded by the United States Department of the Interior's Office of Surface Mining Reclamation and Enforcement (OSM Cooperative Agreement No. S12AC20001).

Acknowledgments: The authors wish to thank the engineers at the drinking water treatment plant facilities at Carbondale, Rend Lake, and Saline Valley Conservancy District in Southern Illinois, United States.

Conflicts of Interest: The authors declare no conflict of interest. The founding sponsors had no role in the design of the study; in the collection, analyses, or interpretation of data; in the writing of the manuscript; and in the decision to publish the results.

\section{References}

1. Trinh, T.K.; Kang, L.S. Response surface methodological approach to optimize the coagulation-flocculation process in drinking water treatment. Chem. Eng. Res. Des. 2011, 89, 1126-1135. [CrossRef]

2. United States Environmental Protection Agency. Drinking Water Treatment Plant Residuals Management Technical Report: Summary of Residuals Generation, Treatment, and Disposal at Large Community Water Systems. 2011. Available online: https:/ / www.epa.gov/sites/production/files/2015-11/documents/dwtreatment-residuals-mgmt-tech-report-sept-2011.pdf (accessed on April 2018).

3. Agyin-Birikorang, S.; O'Connor, G. Aging effects on reactivity of an aluminum-based drinking-water treatment residual as a soil amendment. Sci. Total Environ. 2009, 407, 826-834. [CrossRef] [PubMed]

4. Illinois Environmental Protection Agency (IDPH); Illinois Department of Public Health (IEPA). Final Report on Lead in Public Water Systems; 2017. Available online: http:/ / www.epa.illinois.gov/Assets/iepa/citizens / Lead-PWSFinalReport.pdf (accessed on April 2018).

5. Ahmad, T.; Ahmad, K.; Alam, M. Characterization of Water Treatment Plant's Sludge and its Safe Disposal Options. Procedia Environ. Sci. 2016, 35, 950-955. [CrossRef]

6. Callahan, J.; Johnston, T. Sustainable Solution to the Disposal Epidemic: Beneficial Use of Water Treatment Residual in Manufactured Topsoil. Proc. Water Environ. Fed. 2013, 2013, 140-156. [CrossRef]

7. Castaldi, P.; Mele, E.; Silvetti, M.; Garau, G.; Deiana, S. Water treatment residues as accumulators of oxoanions in soil. Sorption of arsenate and phosphate anions from an aqueous solution. J. Hazard. Mater. 2014, 264, 144-152. [CrossRef] [PubMed]

8. Ippolito, J.; Barbarick, K.; Elliott, H. Drinking water treatment residuals: A review of recent uses. J. Environ. Qual. 2011, 40,1-12. [CrossRef] [PubMed]

9. O'Connor, G.; Elliott, H.; Lu, R. Characterizing water treatment residuals phosphorus retention. Annu. Proc. Soil Crop Sci. Soc. Fla. 2002, 61, 67-73.

10. Schmitt, C.; Hall, J. Analytical characterization of water-treatment-plant sludge. J. AWWA 1975, 67, 40-42. [CrossRef]

11. Titshall, L.; Hughes, J. Characterisation of some South African water treatment residues and implications for land application. Water SA 2005, 31, 299-308. [CrossRef]

12. Chen, H.; Ma, X.; Dai, H. Reuse of water purification sludge as raw material in cement production. Cem. Concr. Compos. 2010, 32, 436-439. [CrossRef]

13. Huang, C.; Pan, J.R.; Liu, Y. Mixing water treatment residual with excavation waste soil in brick and artificial aggregate making. J. Environ. Eng. 2005, 131, 272-277. [CrossRef] 
14. Rodríguez, N.H.; Ramírez, S.M.; Varela, M.B.; Guillem, M.; Puig, J.; Larrotcha, E.; Flores, J. Re-use of drinking water treatment plant (DWTP) sludge: Characterization and technological behaviour of cement mortars with atomized sludge additions. Cem. Concr. Res. 2010, 40, 778-786. [CrossRef]

15. Teixeira, S.; Santos, G.; Souza, A.; Alessio, P.; Souza, S.; Souza, N. The effect of incorporation of a Brazilian water treatment plant sludge on the properties of ceramic materials. Appl. Clay Sci. 2011, 53, 561-565. [CrossRef]

16. Babatunde, A.; Zhao, Y.; Doyle, R.; Rackard, S.; Kumar, J.; Hu, Y. Performance evaluation and prediction for a pilot two-stage on-site constructed wetland system employing dewatered alum sludge as main substrate. Bioresour. Technol. 2011, 102, 5645-5652. [CrossRef] [PubMed]

17. Chiang, Y.W.; Ghyselbrecht, K.; Santos, R.M.; Martens, J.A.; Swennen, R.; Cappuyns, V.; Meesschaert, B. Adsorption of multi-heavy metals onto water treatment residuals: Sorption capacities and applications. Chem. Eng. J. 2012, 200, 405-415. [CrossRef]

18. Chu, W. Dye removal from textile dye wastewater using recycled alum sludge. Water Res. 2001, 35, 3147-3152. [CrossRef]

19. Dayton, E.A.; Basta, N.T.; Jakober, C.A.; Hattey, J.A. Using treatment residuals to reduce phosphorus in agricultural runoff. J. AWWA 2003, 95, 151-158. [CrossRef]

20. Hardy, M.; Makris, K.C.; Sarkar, D.; Datta, R. A Packed Bed Reactor System to Treat Chromium-Contaminated Shipyard Stormwater. In Proceedings of the International Annual Meetings, Agronomy Abstracts, New Orleans, LA, USA, 4-8 November 2007.

21. Hovsepyan, A.; Bonzongo, J.-C.J. Aluminum drinking water treatment residuals (Al-WTRs) as sorbent for mercury: Implications for soil remediation. J. Hazard. Mater. 2009, 164, 73-80. [CrossRef] [PubMed]

22. Makris, K.C.; Sarkar, D.; Datta, R. Aluminum-based drinking-water treatment residuals: A novel sorbent for perchlorate removal. Environ. Pollut. 2006, 140, 9-12. [CrossRef] [PubMed]

23. Quinones, K.D.; Hovsepyan, A.; Oppong-Anane, A.; Bonzongo, J.-C.J. Insights into the mechanisms of mercury sorption onto aluminum based drinking water treatment residuals. J. Hazard. Mater. 2016, 307, 184-192. [CrossRef] [PubMed]

24. Wang, C.; Pei, Y. The removal of hydrogen sulfide in solution by ferric and alum water treatment residuals. Chemosphere 2012, 88, 1178-1183. [CrossRef] [PubMed]

25. Xu, P.; Capito, M.; Cath, T.Y. Selective removal of arsenic and monovalent ions from brackish water reverse osmosis concentrate. J. Hazard. Mater. 2013, 260, 885-891. [CrossRef] [PubMed]

26. Zhao, Y.; Babatunde, A.; Hu, Y.; Kumar, J.; Zhao, X. Pilot field-scale demonstration of a novel alum sludge-based constructed wetland system for enhanced wastewater treatment. Process Biochem. 2011, 46, 278-283. [CrossRef]

27. Codling, E.E. Effects of soil acidity and cropping on solubility of by-product-immobilized phosphorus and extractable aluminum, calcium, and iron from two high-phosphorus soils. Soil Sci. 2008, 173, 552-559. [CrossRef]

28. Fan, J.; He, Z.; Ma, L.Q.; Yang, Y.; Yang, X.; Stoffella, P.J. Immobilization of copper in contaminated sandy soils using calcium water treatment residue. J. Hazard. Mater. 2011, 189, 710-718. [CrossRef] [PubMed]

29. Oladeji, O.O.; Sartain, J.B.; O'Connor, G.A. Land application of aluminum water treatment residual: Aluminum phytoavailability and forage yield. Commun. Soil Sci. Plant Anal. 2009, 40, 1483-1498. [CrossRef]

30. Wang, C.; Zhao, Y.; Pei, Y. Investigation on reusing water treatment residuals to remedy soil contaminated with multiple metals in Baiyin, China. J. Hazard. Mater. 2012, 237, 240-246. [CrossRef] [PubMed]

31. Bartlett, R.; James, B. Studying dried, stored soil samples-Some pitfalls 1. Soil Sci. Soc. Am. J. 1980, 44, 721-724. [CrossRef]

32. Laboratory, R.S. Diagnosis and Improvement of Saline and Alkali Soils; United States Government Publishing Office: Washington, DC, USA, 1954.

33. Wentworth, C.K. A scale of grade and class terms for clastic sediments. J. Geol. 1922, 30, 377-392. [CrossRef]

34. Simard, R. Ammonium acetate-extractable elements. Soil Sampl. Methods Anal. 1993, 1, 39-42.

35. Liang, J.; Karamanos, R. DTPA-extractable Fe, Mn, Cu and Zn. In Soil Sampling and Methods of Analysis; Carter, M.R., Ed.; CRC Press: Boca Raton, FL, USA, 1993; pp. 87-90.

36. Hartz, T. Soil Testing for Nutrient Availability: Procedures and Interpretation for California Vegetable Crop Production; Department of Plant Sciences: Davis, CA, USA, 2007. 
37. Lefticariu, L.; Sutton, S.R.; Bender, K.S.; Lefticariu, M.; Pentrak, M.; Stucki, J.W. Impacts of detrital nano-and micro-scale particles (dNP) on contaminant dynamics in a coal mine AMD treatment system. Sci. Total Environ. 2017, 575, 941-955. [CrossRef] [PubMed]

38. Chen, P.-Y. Table of Key Lines in X-ray Powder Diffraction Patterns of Minerals in Clays and Associated Rocks; Geological Survey: Reston, VA, USA, 1977.

39. American Society of Civil Engineers; American Water Works Association; The United States Environmental Protection Agency. Technology Transfer Handbook: Management of Water Treatment Plant Residuals; ASCE Publications: New York, NY, USA; Denver, CO, USA, 1996.

40. Basta, N.T. Examples and case studies of beneficial reuse of municipal by-products. In Land Application of Agricultural, Industrial, and Municipal by-Products; Soil Science Society of America: Fitchburg, WI, USA, 2000; pp. 481-504.

41. Dayton, E.; Basta, N. Characterization of drinking water treatment residuals for use as a soil substitute. Water Environ. Res. 2001, 73, 52-57. [CrossRef] [PubMed]

42. Elliott, H.; Dempsey, B.; Hamilton, D.; DeWolfe, J. Land Application of Water Treatment Sludges: Impact and Management; American Water Works Association Research Foundation: Denver, CO, USA, 1990.

43. Rengasamy, P.; Oades, J.; Hancock, T. Improvement of soil structure and plant growth by addition of alum sludge. Commun. Soil Sci. Plant. Anal. 1980, 11, 533-545. [CrossRef]

44. Elliott, H.A.; Singer, L.M. Effect of water treatment sludge on growth and elemental composition of tomato (Lycopersicon esculentum) shoots. Commun. Soil Sci. Plant Anal. 1988, 19, 345-354. [CrossRef]

45. Codling, E.E.; Mulchi, C.L.; Chaney, R.L. Biomass yield and phosphorus availability to wheat grown on high phosphorus soils amended with phosphate inactivating residues. II. Iron rich residue. Commun. Soil Sci. Plant Anal. 2002, 33, 1063-1084. [CrossRef]

46. Geertsema, W.S.; Knocke, W.R.; Novak, J.T.; Dove, D. Long-term effects of sludge application to land. J. Am. Water Works Assoc. 1994, 86, 64-74. [CrossRef]

47. Mahdy, A.; Elkhatib, E.; Fathi, N. Drinking water treatment residuals as an amendment to alkaline soils: Effects on the growth of corn and phosphorus extractability. Int. J. Environ. Sci. Technol. 2007, 4, 489-496. [CrossRef]

48. Ippolito, J.A.; Scheckel, K.G.; Barbarick, K.A. Selenium adsorption to aluminum-based water treatment residuals. J. Colloid Interface Sci. 2009, 338, 48-55. [CrossRef] [PubMed]

49. Millaleo, R.; Reyes-Díaz, M.; Ivanov, A.; Mora, M.; Alberdi, M. Manganese as essential and toxic element for plants: Transport, accumulation and resistance mechanisms. J. Soil Sci. Plant Nutr. 2010, 10, 470-481. [CrossRef]

50. Porter, G.; Bajita-Locke, J.; Hue, N.; Strand, D. Manganese solubility and phytotoxicity affected by soil moisture, oxygen levels, and green manure additions. Commun. Soil Sci. Plant Anal. 2004, 35, 99-116. [CrossRef]

51. Fageria, N.; Baligar, V.; Clark, R. Micronutrients in crop production. Adv. Agron. 2002, 77, 185-268.

52. Audebert, A. Diagnosis of risk and approaches to iron toxicity management in lowland rice farming. In Iron Toxicity in Rice-Based Systems in West Africa; Africa Rice Center (WARDA): Cotonou, Benin, 2006; pp. 6-17.

53. Nenova, V. Effect of iron supply on growth and photosystem II efficiency of pea plants. Gen. Appl. Plant Physiol. 2006, 32, 81-90.

54. Whitten, M.; Ritchie, G. Soil tests for aluminum toxicity in the presence of organic matter: Laboratory development and assessment. Commun. Soil Sci. Plant Anal. 1991, 22, 343-368. [CrossRef]

(C) 2018 by the authors. Licensee MDPI, Basel, Switzerland. This article is an open access article distributed under the terms and conditions of the Creative Commons Attribution (CC BY) license (http://creativecommons.org/licenses/by/4.0/). 